\title{
A MARINE RESERVOIR CORRECTION FOR THE HOUTMAN-ABROLHOS ARCHIPELAGO, EAST INDIAN OCEAN, WESTERN AUSTRALIA
}

\author{
Peter Squire ${ }^{1,2}$ • Renaud Joannes-Boyau ${ }^{1}$ Anja M Scheffers ${ }^{1}$ - Luke D Nothdurft ${ }^{3}$ - Quan Hua ${ }^{4}$ \\ Lindsay B Collins ${ }^{5}$-Sander R Scheffers ${ }^{6}$ Jian-xin Zhao ${ }^{7}$
}

\begin{abstract}
High-precision analysis using accelerator mass spectrometry (AMS) was performed upon known-age Holocene and modern, pre-bomb coral samples to generate a marine reservoir age correction value $(\Delta \mathrm{R})$ for the HoutmanAbrolhos Archipelago $\left(28.7^{\circ} \mathrm{S}, 113.8^{\circ} \mathrm{E}\right)$ off the Western Australian coast. The mean $\Delta \mathrm{R}$ value calculated for the Abrolhos Islands, $54 \pm 30 \mathrm{yr}(1 \sigma)$ agrees well with regional $\Delta \mathrm{R}$ values for Leeuwin Current source waters (N-NW Australia-Java) of $60 \pm 38 \mathrm{yr}$. The Abrolhos Islands show little variation with $\Delta \mathrm{R}$ values of the northwestern and north Australian coast, underlining the dominance of the more equilibrated western Pacific-derived waters of the Leeuwin Current over local upwelling. The Abrolhos Islands $\Delta \mathrm{R}$ values have remained stable over the last $2896 \mathrm{cal}$ yr BP, being also attributed to the Leeuwin Current and the El Niño Southern Oscillation (ENSO) signal during this period. Expected future trends will be a strengthening of the teleconnection of the Abrolhos Islands to the climatic patterns of the equatorial Pacific via enhanced ENSO and global warming activity strengthening the Leeuwin Current. The possible effect upon the trend of future $\Delta \mathrm{R}$ values may be to maintain similar values and an increase in stability. However, warming trends of global climate change may cause increasing dissimilarity of $\Delta \mathrm{R}$ values due to the effects of increasing heat stress upon lower-latitude coral communities.
\end{abstract}

\section{INTRODUCTION}

Surface ocean radiocarbon levels are largely representative of the proportionate contributions of atmospheric $\mathrm{CO}_{2}$ and ${ }^{14} \mathrm{C}$-depleted subsurface water DIC, thus making them lower than atmospheric and terrestrial ${ }^{14} \mathrm{C}$. The influence of the "older" ${ }^{14} \mathrm{C}$-depleted carbon source incorporated by marine organisms creates a differential between the marine organism's ${ }^{14} \mathrm{C}$ age and the ${ }^{14} \mathrm{C}$ age of its terrestrial contemporary. The average offset between the marine and terrestrial ${ }^{14} \mathrm{C}$ age $(\sim 400 \mathrm{yr})$ is referred to as the marine reservoir age $(R)$ and is described and accounted for by the application of atmospheric modeling. The marine reservoir age also has regional variation referred to as the marine reservoir correction or $\Delta \mathrm{R}$ value and represents the local influence of ocean and atmospheric mixing due to currents, gyres, upwelling and climatic variations, which vary on seasonal to multidecadal scales (Stuiver and Reimer 1986; Stuiver et al. 1986; Stuiver and Braziunas 1993; Reimer and Reimer 2001).

Around the Australian coastline, especially towards the remote north and northwestern regions and along the East Indian Ocean, there are many gaps in the record of $\Delta \mathrm{R}$ values with low spatial resolution (Reimer and Reimer 2001; Southon et al. 2002; Ulm 2006). In addition, there are several factors that limit the range of existing $\Delta \mathrm{R}$ values available for any chosen analysis. To avoid potential errors when selecting $\Delta \mathrm{R}$ values (or material to sample) for calculating site or regional averages, one must consider beforehand criteria such as: the trophic level and particular feeding habits of sampled organisms; the physicochemical nature of the aquatic environment and habitat of collection; the possibility of diagenetic alteration; and the dating/calibration methods, calculations, and corrections

\footnotetext{
${ }^{1}$ Southern Cross GeoScience, Southern Cross University, Military Rd, Lismore NSW 2480, Australia.

${ }^{2}$ Corresponding author. Email: peter.squire@scu.edu.au.

${ }^{3}$ Earth, Environmental and Biological Sciences, Queensland University of Technology, Gardens Point Campus, GPO Box 2434, Brisbane, QLD 4001, Australia.

${ }^{4}$ Australian Nuclear Science and Technology Organisation (ANSTO), Locked Bag 2001, Kirrawee DC, NSW 2232, Australia. ${ }^{5}$ Department of Applied Geology, Curtin University, Perth WA 6845, Australia.

${ }^{6}$ Marine Ecology Research Centre, School of Environment, Science \& Engineering, Southern Cross University, Lismore NSW 2480, Australia.

${ }^{7}$ School of Earth Sciences, University of Queensland, Brisbane QLD 4072, Australia.
} 
used (Reimer and Reimer 2001; Scholz et al. 2004; Ulm 2006; Nothdurft et al. 2007; Nothdurft and Webb 2009).

Corals represent ideal candidates for calibrating $\Delta \mathrm{R}$ values due to their ability to fix dissolved inorganic carbon (DIC) from the surrounding water column (Grottoli and Eakin 2007). The ${ }^{14} \mathrm{C}$ signatures of their carbonate skeletons reflect the oceanographic conditions integrated over time and are a good proxy for oceanic circulation and climatic processes at subannual to millennial scales (Grottoli and Eakin 2007; McGregor et al. 2011). This paper presents a local marine reservoir correction for the southernmost coral reef complex in the Indian Ocean and evaluates this in context with $\Delta R$ values calculated for the source waters of influential currents including local values in the broader region.

\section{STUDY SITE}

The Abrolhos Archipelago (between $28^{\circ} 04^{\prime} \mathrm{S}$ and $29^{\circ} 27^{\prime} \mathrm{S}$ ) is a series of coral reef islands along the passive shelf margin off the Western Australian coast in the Indian Ocean approximately $70 \mathrm{~km}$ from Geraldton (Figure 1). It is the southernmost coral reef complex in the Indian Ocean, comprising 122 islands in 3 distinct groups: the Pelsaert Group in the south, the Easter Group in the center, and the Wallabi Group in the north. The age structure of the emergent coral reef shingle pavements, underlying reefs, and coral-rubble storm ridges have been reported previously but not extensively or in great detail until sea-level studies performed by Collins et al. (2006) and paleo-tempestological work by Scheffers et al. (2012). The region is considered to be "far field" in terms of tectonism and isostatic adjustment (Collins et al. 2006).

The long-term dominance of the warm, tropically derived waters of the Leeuwin Current is the reason permanent coral communities are established at the Abrolhos Islands in such high latitudes. Compared to other boundary currents around the world, little detailed or extensive study of its hydrodynamics, physicochemical, or ecological aspects occurred in the last 2 decades until the research voyage of the Southern Surveyor in 2003, the findings of which are published in the Deep Sea Research II Special Issue 2007. The Leeuwin Current (LC) is a pole-ward flowing eastern boundary surface current transporting warm, oligotrophic, low-salinity water along the Western Australian seaboard, creating a predominantly downwelling coastline along its route (Pearce and Phillips 1988; Pearce and Pattiaratchi 1999; Hanson et al. 2005; Waite et al. 2007). Source waters for the LC are derived from the Western Pacific Warm Pool (WPWM) via the Indonesian throughflow, the South Equatorial Current, and the Java Current including contributions from the Indian Ocean (Pearce and Phillips 1988; Pearce and Pattiaratchi 1999; Domingues et al. 2007). These source waters are considered to be well mixed and equilibrated with the atmosphere having typically low $\Delta \mathrm{R}$ values around or below 60 yr (Reimer and Reimer 2001; Southon et al. 2002; Hua et al. 2004; Ulm 2006). The strength of the LC varies with seasonal shifts in prevailing wind fields, the effect of which is magnified by ENSO oscillation. During the austral winter, the LC experiences less resistance from opposing south to southwesterly winds arising from the Southern Ocean and is at its peak velocity. During summer, the opposing southerly wind gradient is at its strongest, slowing the LC significantly and occasionally reversing flow direction in some instances. Similarly, when La Niña periods develop the LC flow is enhanced and during El Niño events, subdued (Pearce and Phillips 1988; Pearce and Pattiaratchi 1999; Li and Clarke 2004; Woo et al. 2006; Domingues et al. 2006, 2007; Feng et al. 2007; Waite et al. 2007). During the early to mid-Holocene up to 5000 yr BP, there was a rising ENSO signal with a strengthening of the LC due to a more effective summer monsoon and higher frequency of La Niña events. Since then, there has been a rising El Niño frequency and resulting decline in precipitation and increase in arid conditions. With lower precipitation and surface flows, the vegetation down the NW-W coast of Australia, where the LC operates, has gradually 


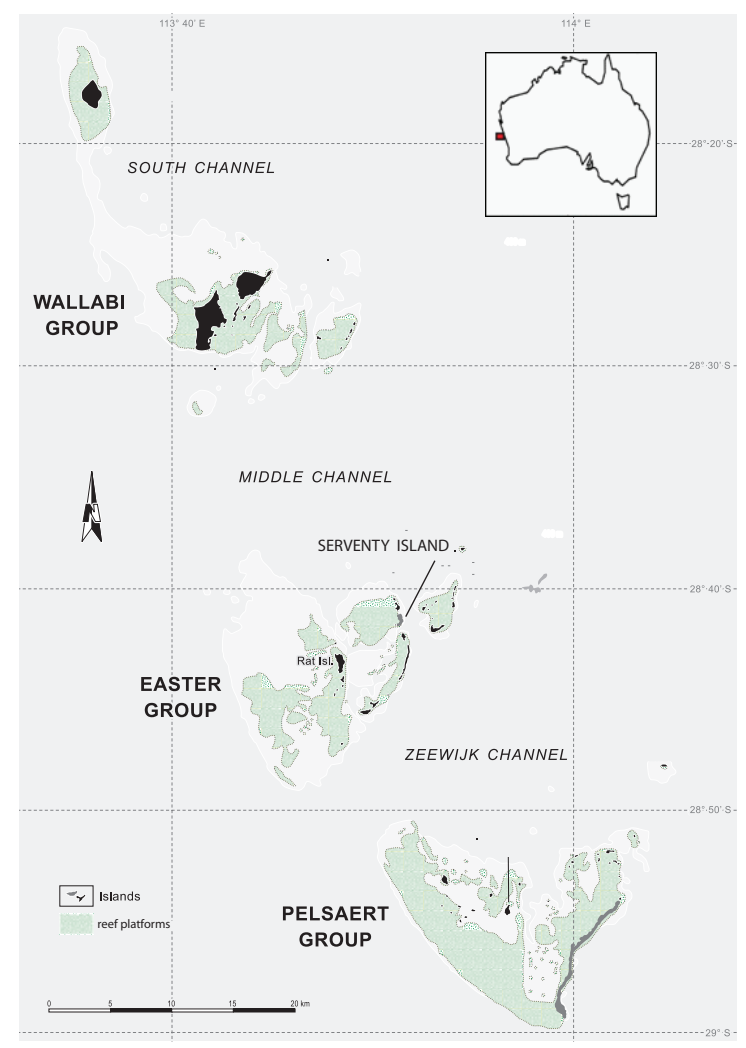

Figure 1 Map of the Abrolhos Islands. Coral samples were taken from Serventy Island. For further details, see Collins et al. (2006).

tended towards semi-desert, giving rise to the modern conditions observed today (van der Kaars and De Deckker 2002; McGregor et al. 2008; McCulloch and Mortimer 2008; Wyrwoll et al. 2009).

\section{MATERIAL AND METHODS}

The sample material used in this study was obtained from the collection of the Collins et al. (2006) sea-level study. The material comprised of coral framework and individual coral samples (mostly Acropora) from storm rubble ridges along the HST2 Sample Traverse on Serventy Island $\left(28.682^{\circ} \mathrm{S}\right.$, $113.835^{\circ} \mathrm{E}$ ). The representative age span of the sample material was about 0.116-7 U-Th ka cal BP. In order to reduce noise or error from interannual variability, sample material for AMS was obtained from coral sections long enough to cover several years of growth along identifiable growth axes $(>7 \mathrm{~cm})$. Suitable candidates were then selected across the available $7000-y r$ age span.

Prior to sampling for AMS, the selected coral pieces were screened for diagenetic alteration at the Earth, Environmental and Biological Sciences, Queensland University of Technology. The coral sections were cut in longitudinal and transverse sections, polished, etched, and carbon coated or left uncoated for observation using an FEI Quanta ${ }^{\mathrm{TM}} 200$ environmental scanning electron microscope (SEM) with energy dispersive spectroscopy (EDS). SEM observations were made in several operation modes, including operation at high vacuum (15 and $20 \mathrm{kV}$ ) on samples coated with carbon and at $2-10 \mathrm{kV}$ for uncoated samples using both secondary and backscattered electron imaging. Secondary electron images were made from freshly broken and external surfaces, with some specimens 
etched with dilute formic acid (2\%) for 20 s prior to being carbon coated. Carbonate polymorphs and other minerals were identified in situ on broken, sawn, and polished sections (Nothdurft and Webb 2009). The sample material deemed suitable for AMS analysis after screening had a resultant age span of 0.116-4.334 U-Th ka cal BP (Table 1).

Sample material for AMS analysis was carefully removed from the larger central coral mass along the growth axes with a dental drill. The samples were cleaned with deionized water in an ultrasonic bath twice for 40 min each to remove any surface contamination. They were then dried in an oven at $60{ }^{\circ} \mathrm{C}$ for 2 days before hydrolysis. The cleaned samples were hydrolyzed to $\mathrm{CO}_{2}$ using $85 \%$ phosphoric acid. The $\mathrm{CO}_{2}$ samples were then converted to graphite using the $\mathrm{H}_{2} / \mathrm{Fe}$ method (Hua et al. 2001). A small portion of graphite from each sample was employed in the determination of $\delta^{13} \mathrm{C}$ using the Micromass IsoPrime elemental analyzer/isotope ratio mass spectrometer (EA/IRMS) at ANSTO. AMS ${ }^{14} \mathrm{C}$ measurements were performed using the STAR facility at ANSTO (Lawson et al. 2000; Fink et al. 2004) with a precision of 0.3-0.4\%.

\section{RESULTS}

The U-series isotopic data from Collins et al. (2006) correspond with our AMS samples and are listed in Table 1 . Results of the AMS ${ }^{14} \mathrm{C}$ analysis of our samples are shown in Table 2 . The $\Delta \mathrm{R}$ values for the Abrolhos Islands were calculated as the difference between the conventional ${ }^{14} \mathrm{C}$ age after correction for $\delta^{13} \mathrm{C}$ (Stuiver and Polach 1977) and the model age (Marine09; Reimer et al. 2009) of U/Th age (cal yr BP). When calculating a mean $\Delta \mathrm{R}$ correction, in order to be compatible with the online marine reservoir correction database (Reimer and Reimer 2001), the uncertainty associated with an error-weighted mean $\Delta \mathrm{R}$ was chosen as the larger of the error of the mean and the standard deviation.

Coral samples 5000 U-Th cal BP and older did not pass the initial diagenetic screening and were rejected for AMS analysis. There were 3 anomalous results for samples OZO421 (HST1-PAVE), OZO422 (HST2-R3), and OZO426 (HST2-R9) with large, negative $\Delta \mathrm{R}$ values (Table 2). Low $\delta^{13} \mathrm{C}$ values present in these results may indicate exposure of sample material to freshwater (Southon et al. 2002) and subsequent diagenetic effects and/or geological alteration-a common occurrence in emergent pavements and coral rubble ridges exposed above sea level (Nothdurft et al. 2007; Nothdurft and Webb 2009). Nevertheless, low $\delta^{13} \mathrm{C}$ values seem not to consistently affect the AMS results, suggesting that poor sample quality is related to other forms of degradation or a combination of both. The 3 anomalous samples showed advanced signs of microboring, the presence of gypsum, and some sponge chips at the surface margins. To avoid any diagenetically altered material, samples were carefully extracted from the central mass of the coral. Unfortunately, as large $(>7 \mathrm{~cm})$ sections of material were sampled, the possibility of contamination was greatly enhanced. These data were subsequently treated as outliers and were excluded from the mean $\Delta \mathrm{R}$ calculation.

Loss or gain of initial uranium or daughter isotopes from the sample material, due to means other than radioactive decay, may lead to under- or overestimation (bias) of age determinations. Uranium levels (U ppm, Table 1) were elevated as may be expected for scleractinian corals. However, bias is still possible via $\mathrm{U}^{234}$ and ${ }^{234} \mathrm{Th}-\mathrm{Th}^{230}$ mobility during late diagenesis of rubble ridges and porous coral framestone pavement exposed to cementation processes in semi-arid conditions (Zhu et al. 1993; Stirling et al. 1995; Hillaire-Marcel 2009). Though the XRD calcite screening threshold (with associated sensitivity-precision issues) was at 2\% (Collins et al. 2006) instead of the recommended $\leq 1 \%$ (Hughen et al. 2004; Robinson et al. 2006; Hillaire-Marcel 2009), the well-constrained errors observed in the U-Th dates suggest authigenic U-buffering against open system behavior and provide a good minimum age estimate. 


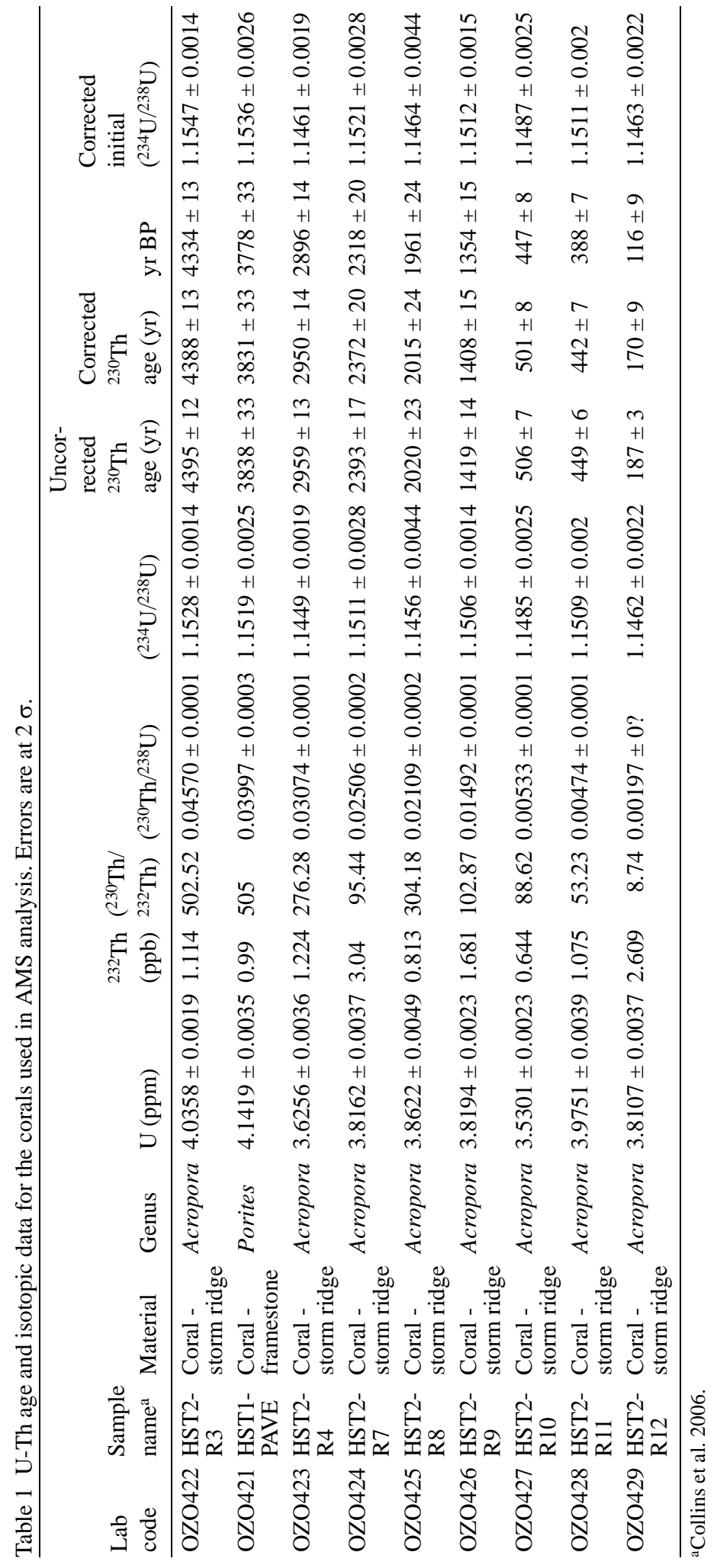


Table $2 \Delta \mathrm{R}$ values and AMS results for the Abrolhos Archipelago (Serventy Island). Year of growth or collection is 2002 for all samples.

\begin{tabular}{|c|c|c|c|c|c|c|c|}
\hline $\begin{array}{l}\text { Lab } \\
\text { code }\end{array}$ & $\begin{array}{l}\text { Sample } \\
\text { name }^{\mathrm{a}}\end{array}$ & $\begin{array}{l}\text { U/Th age } \\
\text { before } 1950 \\
\text { (cal yr BP) } 2 \sigma\end{array}$ & Species & $\begin{array}{l}\delta^{13} \mathrm{C} \\
\text { (\%o) }\end{array}$ & $\begin{array}{l}\text { Conventional } \\
{ }^{14} \mathrm{C} \text { age } \\
\text { (yr BP) } 1 \sigma\end{array}$ & $\begin{array}{l}\text { Model age } \\
\text { (yr BP) } 1 \sigma\end{array}$ & $\begin{array}{l}\Delta \mathrm{R}\left({ }^{14} \mathrm{C} \mathrm{yr}\right) \\
1 \sigma\end{array}$ \\
\hline OZO422 & HST2-R3 & $4334 \pm 13$ & Acropora & -1 & $4085 \pm 35$ & $4215 \pm 5$ & $-130 \pm 35^{c}$ \\
\hline OZO421 & HST1-PAVE & $3778 \pm 33$ & Porites & -0.2 & $3695 \pm 35$ & $3820 \pm 5$ & $-125 \pm 35^{c}$ \\
\hline OZO423 & HST2-R4 & $2896 \pm 14$ & Acropora & -1.9 & $3155 \pm 35$ & $3125 \pm 5$ & $30 \pm 35$ \\
\hline OZO424 & HST2-R7 & $2318 \pm 20$ & Acropora & -1.9 & $2690 \pm 35$ & $2635 \pm 25$ & $55 \pm 43$ \\
\hline OZO425 & HST2-R8 & $1961 \pm 24$ & Acropora & -1.3 & $2410 \pm 35$ & $2345 \pm 5$ & $65 \pm 35$ \\
\hline OZO426 & HST2-R9 & $1354 \pm 15$ & Acropora & -1.6 & $1740 \pm 30$ & $1825 \pm 5$ & $-85 \pm 30^{c}$ \\
\hline OZO427 & HST2-R10 & $447 \pm 8$ & Acropora & -1.5 & $800 \pm 30$ & $790 \pm 5$ & $10 \pm 30$ \\
\hline OZO428 & HST2-R11 & $388 \pm 7$ & Acropora & 0.3 & $805 \pm 30$ & $730 \pm 5$ & $75 \pm 30$ \\
\hline OZO429 & HST2-R12 & $116 \pm 9$ & Acropora & -1 & $575 \pm 30$ & $\begin{array}{r}490 \pm 5 \\
\text { Mean }\end{array}$ & $\begin{array}{l}85 \pm 30 \\
54 \pm 30\end{array}$ \\
\hline
\end{tabular}

a Collins et al. 2006.

${ }^{\mathrm{b}}$ Calculated using U-Th ages for the Abrolhos Islands (see Table 1).

cThese values were treated as outliers and removed from the calculation of the mean $\Delta \mathrm{R}$.

Table 3 Pre-bomb regional and local $\Delta \mathrm{R}$ values of previous studies. NB: Values in bold type denote regional and subregional averages.

\begin{tabular}{|c|c|c|c|c|}
\hline Region or location & Lat $\left({ }^{\circ} \mathrm{S}\right)$ & Long $\left({ }^{\circ} \mathrm{E}\right)$ & References & $\Delta \mathrm{R}(\mathrm{yr})$ \\
\hline Pelabuhanratu, Java $(n=1)$ & 7 & 106.5 & Southon et al. 2002 & $42 \pm 70$ \\
\hline $\begin{array}{l}\text { Torres Strait, Australia } \\
(n=3)\end{array}$ & 10 & 143 & $\begin{array}{l}\text { Gillespie 1977; Gillespie and Polach } \\
1979\end{array}$ & $50 \pm 45$ \\
\hline $\begin{array}{l}\text { Northern Territory, Australia } \\
(n=1)\end{array}$ & 11.3 & 132.4 & Southon et al. 2002 & $59 \pm 40$ \\
\hline $\begin{array}{l}\text { Cocos (Keeling Islands), } \\
\text { Australia }(n=12)\end{array}$ & 12 & 97 & Hua et al. 2004 and references therein & $64 \pm 15$ \\
\hline $\begin{array}{l}\text { Kimberley region, Australia } \\
(n=9)\end{array}$ & $16.4-18.1$ & $122.2-123$ & Bowman 1985; O’Connor et al. 2010 & $58 \pm 19$ \\
\hline $\begin{array}{l}\text { Abrolhos Islands (Serventy } \\
\text { Island), Australia }(n=6)\end{array}$ & 28 & 114 & This study & $54 \pm 30$ \\
\hline $\begin{array}{l}\text { Rowley Shoals, Kimberley } \\
\text { Region, Australia }(n=13)\end{array}$ & 17.3 & 119.15 & Unpublished data - AINSE grant 11/085 & $60 \pm 44$ \\
\hline Southwestern Australia & $32.3-35$ & 115.7-116.5 & $\begin{array}{l}\text { Gillespie 1977; Gillespie and Polach } \\
\text { 1979; Bowman and Harvey 1983; Bow- } \\
\text { man } 1985\end{array}$ & $71 \pm 47$ \\
\hline $\begin{array}{l}\text { Java - Cocos Islands - Torres } \\
\text { Strait - Kimberley }(n=26)\end{array}$ & $7-18.1$ & $97-123$ & References within this table & $60 \pm 38$ \\
\hline
\end{tabular}

Summarized in Table 3 and displayed graphically in Figures 2 and 3 are individual location and subregional mean $\Delta \mathrm{R}$ values for the contributing source waters of the Leeuwin Current (LC). The areal coverage extends from Indonesia and the Cocos (Keeling) Islands to Torres Strait and across the Northern Territory to the Kimberley region. These end-members represent waters from the Western Pacific Warm Pool, i.e. the Indonesian throughflow and South Equatorial Current including also the West Indian Ocean and Java Current. Included for comparison are some of the southernmost regions influenced by the LC. Data were selected from the Reimer and Reimer (2001) database best reflecting the ambient conditions of oceanic/coastal waters. On this basis, corals (where possible) were prioritized and only bivalve shells of suspension-feeding species were selected. To avoid the problem of “older” depleted carbon signals (i.e. from contamination by terrestrial/local sediments), shell specimens were excluded from selection if they belonged to a deposit-feeding genus. Similarly, any material was rejected if originating from estuarine/enclosed waters, were of unknown feeding habit or from uncertain location. The only exception to this rule was a specimen of the Thais genus from 
Pelebuhanratu (Java), Indonesia. Though an intertidal carnivore, this genus feeds mostly on herbivorous filter feeders and is also capable of directly sourcing food in suspension (Lau and Leung 2004). As this species is used as a bioindicator for heavy metals and various other marine contaminants accumulated via their prey, it must be selected with caution. However, because this specimen was collected in 1910 (Southon et al. 2002) and from a location near a historically remote fishing village known for its strong surf conditions, it may be assumed that the local well-mixed surface marine conditions are reflected, as its low $\Delta \mathrm{R}$ value suggests. All calculated regional-subregional mean $\Delta \mathrm{R}$ values are also error-weighted according to Reimer and Reimer (2001), where the uncertainty associated with an error-weighted mean $\Delta \mathrm{R}$ was chosen as the larger of the error of the mean and the standard deviation.

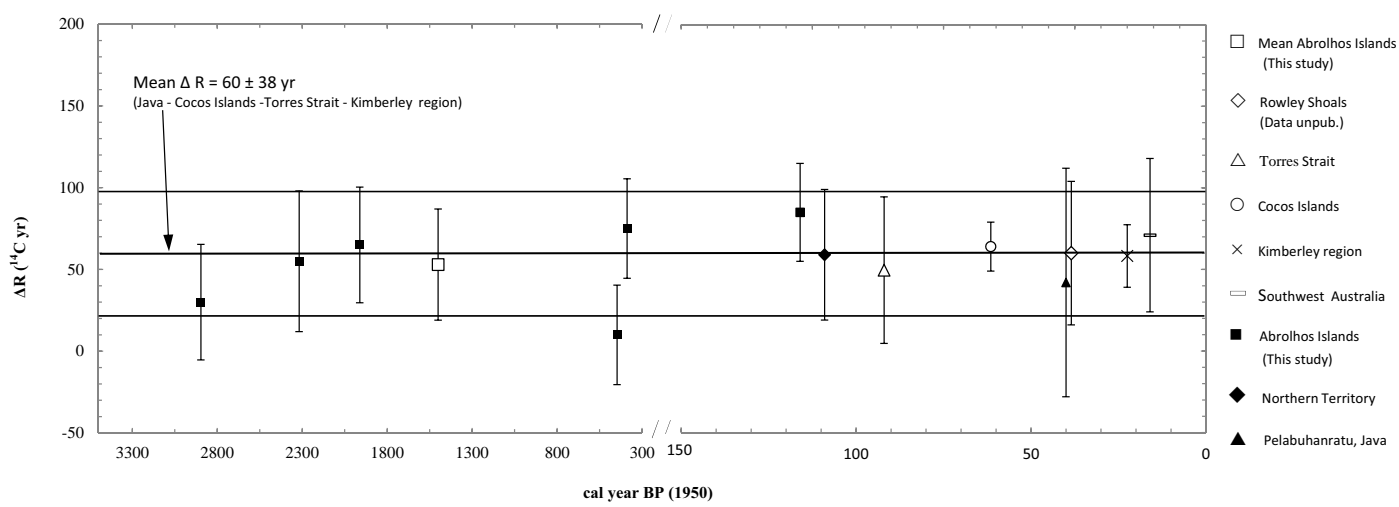

Figure 2 Abrolhos $\Delta \mathrm{R}$ values regional/subregional and individual $\Delta \mathrm{R}$ values from Table 3. NB: For convenience of plotting, for data from studies using different dating methods, the dates of all $\Delta \mathrm{R}$ values were converted to cal yr $\mathrm{BP}$. The Abrolhos data were plotted against their U-Th dates (see Table 2).

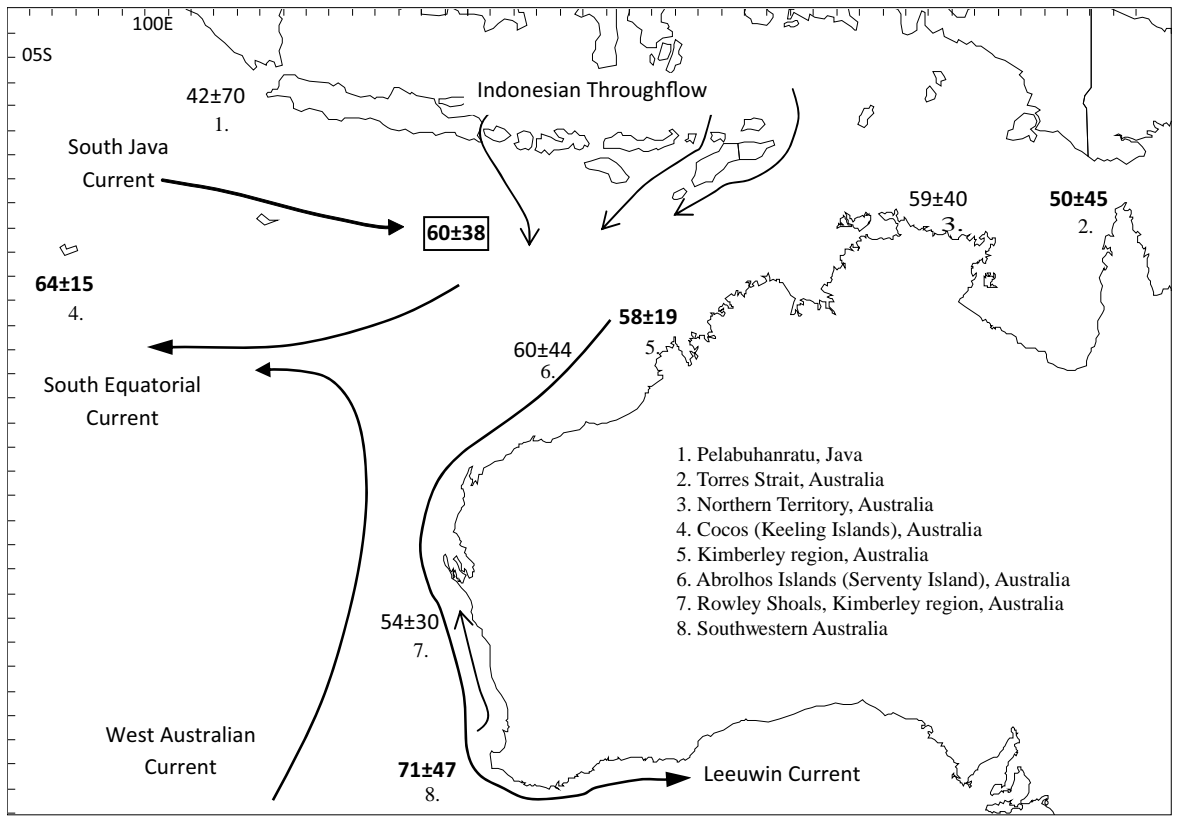

Figure 3 Location of $\Delta \mathrm{R}$ values from Table 3 in relation to surface currents. Regional/subregional values are in bold type and the Leeuwin Current source-water mean is boxed. 
The range of $\Delta \mathrm{R}$ values for the Abrolhos Islands (10-85 yr) shows little variation about a mean $\Delta \mathrm{R}$ of $54 \pm 30$ over $2896 \pm 14$ cal yr BP to historical times (Table 2). The $\Delta \mathrm{R}$ values overlap with each other at $1 \sigma$ uncertainty except for the fourth oldest and lowest $\Delta \mathrm{R}$ value $(10 \pm 30 \mathrm{yr})$ with the 2 youngest samples (Figure 2). All individual Abrolhos $\Delta \mathrm{R}$ values overlap within $1 \sigma$ uncertainty of the regional $\Delta \mathrm{R}$ of $60 \pm 38 \mathrm{yr}$ calculated for LC source waters from NW Australia to Java (Figure 2). Apart from the minor deviation of this single value, the Abrolhos data is well constrained by this "regional" mean and its $\Delta \mathrm{R}$ uncertainty.

\section{DISCUSSION}

The mean $\Delta \mathrm{R}$ value for the Abrolhos Islands $(54 \pm 30)$ at $28.45^{\circ} \mathrm{S}$ is similar to those found in tropical latitudes to the north. For example, the Rowley Shoals, with its central position relative to the Leeuwin Current (LC) source water end-members, has a mean $\Delta \mathrm{R}$ of $60 \pm 44 \mathrm{yr}$, relatively equal to the calculated average regional $\Delta \mathrm{R}$ of $60 \pm 38 \mathrm{yr}$ (Figure 2). The close agreement of mean $\Delta \mathrm{R}$ values from the Abrolhos and tropical regions indicates the long-range influence of the well-equilibrated source waters of the LC (Figure 2, Table 3).

The $\Delta \mathrm{R}$ values at the Abrolhos are relatively stable over the last $\sim 3000 \mathrm{yr}$. This apparent stability occurs during the rise in frequency of El Niño versus La Niña patterns up to the present time in the trend towards modern conditions seen in the western Pacific with more protracted and higher amplitude El Niño events (e.g. McGregor et al. 2008; Yu et al. 2010). Factors responsible for the stability of the $\Delta \mathrm{R}$ signal at the Abrolhos over the last $3000 \mathrm{yr}$ also include minimal tectonic activity, oceanographic simplicity, and a smooth, mostly linear sea-level decline after the Holocene highstand (Collins et al. 2006; Ulm 2006; Burr et al. 2009; Petchey et al. 2009). The coastline of Western Australia has not been subject to the degree of local tectonism, hydro-isostatic variability (hence sealevel fluctuation), upwelling and mixing of waters of very different physicochemical nature as experienced by many islands and coastlines of the East Indian Ocean and eastern and central Pacific regions (Southon et al. 2002; Burr et al. 2009; Petchey et al. 2009).

The position of the Abrolhos Islands just before the continental shelf slope is another factor governing the long-term stability of $\Delta \mathrm{R}$ values. The LC core is anchored to the shelf break and is centered on the 200-m isobath just seaward of the Abrolhos where there is an acceleration of current speed (Woo et al. 2006). This ensures that the Abrolhos Islands remain predominantly within the LC influence (and periodically engulfed by the LC) for much longer than experienced seasonally on the mainland coast and is more protected from upwelling events (Hanson et al. 2005). A strong meridional pressure gradient generates the LC southward flow against the southwesterly wind fields, suppressing Ekman transport and creating a predominantly downwelling coast from Cape Range south to Cape Leeuwin (Pearce and Pattiaratchi 1999; Waite et al. 2007). However, as the LC travels from the lower-latitude source waters, transporting heat and low-salinity water southwards, heat loss and salinity increases with the gradual geostrophic contribution of Indian Ocean surface waters. Potentially, during this process the heat loss may induce convective mixing of underlying waters below the LC (Feng et al. 2007; Waite et al. 2007).

Upwelling along the Western Australian coastline is mostly sporadic and located around topographical features of the shelf break occurring mainly south of $34^{\circ}$ latitude. Studies have indicated that the Capes Current (CC) flowing northward from $34^{\circ} \mathrm{S}$ may be a source of upwelled water transported inside the LC over nearshore shelf waters to just north of the Abrolhos Islands chain near Shark Bay (Woo et al. 2006; Feng et al. 2007; Waite et al. 2007). Analysis of the composition of this water reveal that the CC is a relatively weak source compared to upwelling experienced in other eastern boundary currents (Woo et al. 2006). Often, by the time any upwelled water from the south arrives 
near the Abrolhos it is well mixed with LC waters that have been subject to geostrophic contribution of surface central Indian Ocean water (Woo et al. 2006; Feng et al. 2007). Some upwelling has been reported off-shelf near the Abrolhos Islands and coastward shelf waters (Hatcher et al. 1987; Hatcher 1991) and possibly Ningaloo Reef to the far north but not directly observed or measured recently (Kuhnert et al. 1999, 2000; Woo et al. 2006; Feng et al. 2007; Waite et al. 2007). Two mesoscale counter-rotating cold- and warm-core eddies generated from detached LC meanders operate seasonally near the Abrolhos Islands, centered between $111^{\circ} 37.7^{\prime} \mathrm{E}, 31^{\circ} 19.20^{\prime} \mathrm{S}$ and $110^{\circ} 1.5^{\prime} \mathrm{E}, 30^{\circ} 56.7^{\prime} \mathrm{S}$. These systems have the potential to advect deeper waters or cause localized upwelling, though detailed analysis of their structure revealed no upwelling (Feng et al. 2007; Waite et al. 2007).

Most of the $\delta^{18} \mathrm{O}$ variability observed in coral cores taken from the Abrolhos Islands has been attributed to the localized influence upon sea surface temperatures by spatial LC mobility around the archipelago and the associated lateral advection of nearby off-shelf and shelf surface waters as a result of local weather and LC strength. The magnitude of variability in these factors is influenced predominantly by ENSO fluctuations (Kuhnert et al. 1999). If upwelling were significant for this region, then it would be expected that the depleted ${ }^{14} \mathrm{C}$ signal be apparent in the coral skeletons. During the austral summer, when corals at this high latitude are experiencing peak growth rates, the LC is usually at its least strength due to the opposing prevailing wind gradient. The potential for upwelling events is enhanced by these conditions and also the probability for the capture of these events within the coral skeleton. In tandem, the highest proportion of several years' worth of skeletal coral growth sampled is represented by summer growth, as the very low water temperatures of the Abrolhos in winter are responsible for little skeletal development (Kuhnert et al. 1999). If upwelling events were frequent, considering the above factors, it would be expected that the sample bias would be towards higher $\Delta \mathrm{R}$ values over most of the last $3000 \mathrm{cal}$ yr BP (especially as El Niño events became more frequent). Instead, the $\Delta \mathrm{R}$ values observed are low and more similar to latitudes up to $20^{\circ}$ further to the north. However, apart from the study site, there remains the possibility of spatial heterogeneity of $\Delta \mathrm{R}$ values across the Abrolhos Islands due to localized influences of channel bathymetry and differences in shelter or exposure to offshore conditions including the seasonal and ENSO-related pentadal vagaries of the LC.

In the future, it is likely that the climatic teleconnection of the subtropical/warm temperate Abrolhos Islands with waters of lower latitudes around Rowley Shoals and further north to Indonesia will become stronger and reinforce the similarity of $\Delta \mathrm{R}$ values. Review of $\delta^{18} \mathrm{O}$ coral band records longer than 20 to $350 \mathrm{yr}$ around the world (including the Abrolhos and Ningaloo reefs) suggest a warming and freshening trend of surface waters as ENSO and monsoonal patterns intensify, including also the impact of anthropogenic warming (Kuhnert et al. 1999, 2000; Grottoli and Eakin 2007; Wyrwoll et al. 2009). The effect of this would possibly be to strengthen the LC and increase its influence, enhancing the trend towards more Pleistocene-like conditions (Wyrwoll et al. 2009). It is possible that as more Equator-ward corals become stressed as they approach bleaching point that there may be a divergence of similarity of $\Delta \mathrm{R}$ between the Abrolhos and northern waters even though the climatic connection becomes stronger.

\section{CONCLUSIONS}

A local average marine reservoir $\Delta \mathrm{R}$ correction value was determined for the Abrolhos Archipelago (54 $\pm 30 \mathrm{yr}$ ). The $\Delta \mathrm{R}$ value agrees well with the regional average for N-NW Australia and Java of $60 \pm 38 \mathrm{yr}$. The Abrolhos Islands $\Delta \mathrm{R}$ values have remained stable over the last $2896 \mathrm{cal}$ yr BP due to the increasing strength of the LC and minimal upwelling. Potential future trends may be a 
strengthening of the teleconnection of the Abrolhos Islands to the climatic patterns of the equatorial Pacific via enhanced ENSO and global warming activity strengthening the LC. The possible effect on future $\Delta \mathrm{R}$ values at the Abrolhos would be to maintain similar low values and a likely increase in stability. However, warming trends of global climate change may cause increasing dissimilarity of $\Delta \mathrm{R}$ values to regions of the north due to the effects of increasing heat stress on coral communities in lower latitudes.

\section{ACKNOWLEDGMENTS}

The authors wish to thank ANSTO, QUT, and UQ laboratory staff for their assistance. Thanks also to Prof Malcolm McCulloch from the School of Earth and Environment, University of Western Australia for helpful comments. We gratefully acknowledge funding from the Australian Institute of Nuclear Science and Engineering (AINSE) for AMS ${ }^{14} \mathrm{C}$ measurements (grants 11/074 and 11/085).

\section{REFERENCES}

Bowman GM. 1985. Oceanic reservoir correction for marine radiocarbon dates from northwestern Australia. Australian Archaeology 20:58-67.

Bowman G, Harvey N. 1983. Radiocarbon dating marine shells in South Australia. Australian Archaeology 17: 113-23.

Burr GS, Beck JW, Corrège T, Cabioch G, Taylor FW, Donahue DJ. 2009. Modern and Pleistocene reservoir ages inferred from South Pacific corals. Radiocarbon 51(1):319-35.

Collins LB, Zhao J-X, Freeman H. 2006. A high-precision record of mid-late Holocene sea-level events from emergent coral pavements in the Houtman Abrolhos Islands, southwest Australia. Quaternary International 145-146:78-85.

Domingues CM, Wijffels SE, Maltrud ME, Church JA, Tomczak M. 2006. Role of eddies in cooling the Leeuwin Current. Geophysical Research Letters 33(5): L05603, doi: 10.1029/2005GL025216.

Domingues CM, Maltrud ME, Wijffels SE, Church JA, Tomczak M. 2007. Simulated Lagrangian pathways between the Leeuwin Current System and the upperocean circulation of the southeast Indian Ocean. Deep-Sea Research II 54(8-10):797-817.

Feng M, Majewski LJ, Fandry C, Waite AM. 2007. Characteristics of two counter-rotating eddies in the Leeuwin Current system off the Western Australian coast. Deep-Sea Research II 54(8-10):961-80.

Fink D, Hotchkiss M, Hua Q, Jacobsen G, Smith A, Zoppi U, Child D, Mifsud C, van der Gaast H, Williams A. 2004. The ANTARES AMS facility at ANSTO. Nuclear Instruments and Methods in Physics Research B 223-224:109-15.

Gillespie R. 1977. Sydney University natural radiocarbon measurements IV. Radiocarbon 19(1):101-10.

Gillespie R, Polach H. 1979. The suitability of marine shells for radiocarbon dating of Australian prehistory. In: Berger R, Suess H, editors. Proceedings of the 9th International Conference on Radiocarbon Dating. Los Angeles: University of California Press. p 404-21.
Grottoli AG, Eakin CM. 2007. A review of modern coral $\delta^{18} \mathrm{O}$ and $\Delta^{14} \mathrm{C}$ proxy records. Earth-Science Reviews 81(1-2):67-91.

Hanson CE, Pattiaratchi CB, Waite AM. 2005. Sporadic upwelling on a downwelling coast: phytoplankton responses to spatially variable nutrient dynamics off the Gascoyne region of Western Australia. Continental Shelf Research 25(12-13):1561-82.

Hatcher B. 1991. Coral reefs in the Leeuwin Current-an ecological perspective. Journal of the Royal Society of Western Australia 74:115-27.

Hatcher B, Kirkman H, Wood W. 1987. Growth of the kelp Ecklonia radiata near the northern limit of its range in Western Australia. Marine Biology 95(1):6373.

Hillaire-Marcel C. 2009. The U-series dating of (biogenic) carbonates. IOP Conference Series: Earth and Environmental Science 5(1):12008.

Hua Q, Jacobsen GE, Zoppi U, Lawson EM, Williams AA, Smith AM, McGann MJ. 2001. Progress in radiocarbon target preparation at the ANTARES AMS Centre. Radiocarbon 43(2A):275-82.

Hua Q, Woodroffe C, Barbetti M, Smithers S, Zoppi U, Fink D. 2004. Marine reservoir correction for the Cocos (Keeling) Islands, Indian Ocean. Radiocarbon 46(2):603-10.

Hughen KA, Baillie MGL, Bard E, Beck JW, Bertrand CJH, Blackwell PG, Buck CE, Burr GS, Cutler KB, Damon PE, Edwards RL, Fairbanks RG, Friedrich M, Guilderson TP, Kromer B, McCormac G, Manning S, Bronk Ramsey C, Reimer PJ, Reimer RW, Remmele S, Southon JR, Stuiver M, Talamo S, Taylor FW, van der Plicht J, Weyhenmeyer CE. 2004. Marine04 marine radiocarbon age calibration, 0-26 cal kyr BP. Radiocarbon 46(3):1059-86.

Kuhnert H, Pätzold J, Hatcher B, Wyrwoll KH, Eisenhauer A, Collins L, Zhu Z, Wefer G. 1999. A 200-year coral stable oxygen isotope record from a high-latitude reef off Western Australia. Coral Reefs 18(1):112. 
Kuhnert H, Pätzold J, Wyrwoll KH, Wefer G. 2000. Monitoring climate variability over the past 116 years in coral oxygen isotopes from Ningaloo Reef, Western Australia. International Journal of Earth Sciences 88(4):725-32.

Lau DCP, Leung KMY. 2004. Feeding physiology of the carnivorous gastropod Thais clavigera (Kuster): do they eat "soup"? Journal of Experimental Marine Biology and Ecology 312(1):43-66.

Lawson E, Elliott G, Fallon J, Fink D, Hotchkis M, Hua Q, Jacobsen G, Lee P, Smith A, Tuniz C, Zoppi U. 2000. AMS at ANTARES- the first 10 years. Nuclear Instruments and Methods in Physics Research $B$ 172(1-4):95-9.

Li J, Clarke AJ. 2004. Coastline direction, interannual flow, and the strong El Niño currents along Australia's nearly zonal southern coast. Journal of Physical Oceanography 34(11):2373-81.

McCulloch M, Mortimer G. 2008. Applications of the ${ }^{238} \mathrm{U} \_{ }^{230} \mathrm{Th}$ decay series to dating of fossil and modern corals using MC-ICPMS. Australian Journal of Earth Sciences 55(6-7):955-65.

McGregor H, Gagan M, McCulloch M, Hodge E, Mortimer G. 2008. Mid-Holocene variability in the marine ${ }^{14} \mathrm{C}$ reservoir age for northern coastal Papua New Guinea. Quaternary Geochronology 3(3):21325.

McGregor HV, Hellstrom J, Fink D, Hua Q, Woodroffe CD. 2011. Rapid U-series dating of young fossil corals by laser ablation MC-ICPMS. Quaternary Geochronology 6(2):195-206.

Nothdurft L, Webb G. 2009. Earliest diagenesis in scleractinian coral skeletons: implications for palaeoclimate-sensitive geochemical archives. Facies 55(2): 161-201.

Nothdurft LD, Webb GE, Bostrom T, Rintoul L. 2007. Calcite-filled borings in the most recently deposited skeleton in live-collected Porites (Scleractinia): implications for trace element archives. Geochimica et Cosmochimica Acta 71(22):5423-38.

O’Connor S, Ulm S, Fallon S, Barham A, Loch I. 2010. Pre-bomb marine reservoir variability in the Kimberley region, western Australia. Radiocarbon 52(3): 1158-65.

Pearce A, Pattiaratchi C. 1999. The Capes Current: a summer countercurrent flowing past Cape Leeuwin and Cape Naturaliste, Western Australia. Continental Shelf Research 19(3):401-20.

Pearce A, Phillips B. 1988. ENSO events, the Leeuwin Current, and larval recruitment of the western rock lobster. ICES Journal of Marine Science 45(1):13-21.

Petchey F, Allen MS, Addison DJ, Anderson A. 2009. Stability in the South Pacific surface marine ${ }^{14} \mathrm{C}$ reservoir over the last 750 years. Evidence from American Samoa, the southern Cook Islands and the Marquesas. Journal of Archaeological Science 36(10): 2234-43.

Reimer PJ, Reimer R. 2001. A marine reservoir correc- tion database and on-line interface. Radiocarbon 43(2A):461-3.

Reimer PJ, Baillie MGL, Bard E, Bayliss A, Beck JW, Blackwell PG, Bronk Ramsey C, Buck CE, Burr GS, Edwards RL, Friedrich M, Grootes PM, Guilderson TP, Hajdas I, Heaton TJ, Hogg AG, Hughen KA, Kaiser KF, Kromer B, McCormac FG, Manning SW, Reimer RW, Richards DA, Southon JR, Talamo S, Turney CSM, van der Plicht J, Weyhenmeyer CE. 2009. IntCal09 and Marine09 radiocarbon age calibration curves, 0-50,000 years cal BP. Radiocarbon 51(4): 1111-50.

Robinson LF, Adkins JF, Fernandez DP, Burnett DS, Wang S-L, Gagnon AC, Krakauer N. 2006. Primary U distribution in scleractinian corals and its implications for U series dating. Geochemistry, Geophysics, Geosystems 7(5):Q05022.

Scheffers AM, Scheffers SR, Kelletat DH, Squire P, Collins L, Feng Y, Zhao J-X, Joannes-Boyau R, May SM, Schellmann G, Freeman H. 2012. Coarse clast ridge sequences as suitable archives for past storm events? Case study on the Houtman Abrolhos, Western Australia. Journal of Quaternary Science 27(7):713-24.

Scholz D, Mangini A, Felis T. 2004. U-series dating of diagenetically altered fossil reef corals. Earth and Planetary Science Letters 218(1-2):163-78.

Southon J, Kashgarian M, Fontugne M, Metivier B, Yim WW-S. 2002. Marine reservoir corrections for the Indian Ocean and Southeast Asia. Radiocarbon 44(1): 167-80.

Stirling C, Esat T, McCulloch M, Lambeck K. 1995. High-precision U-series dating of corals from Western Australia and implications for the timing and duration of the Last Interglacial. Earth and Planetary Science Letters 135(1-4):115-30.

Stuiver M, Braziunas TF. 1993. Modeling atmospheric ${ }^{14} \mathrm{C}$ influences and ${ }^{14} \mathrm{C}$ ages of marine samples to 10,000 BC. Radiocarbon 35(1):137-89.

Stuiver M, Polach HA. 1977. Discussion: reporting of ${ }^{14} \mathrm{C}$ data. Radiocarbon 19(3):355-63.

Stuiver M, Reimer PJ. 1986. A computer program for radiocarbon age calibration. Radiocarbon 28(2B): 1022-30.

Stuiver M, Pearson GW, Braziunas TF. 1986. Radiocarbon age calibration of marine samples back to 9000 cal yr BP. Radiocarbon 28(2B):980-1021.

Ulm S. 2006. Australian marine reservoir effects: a guide to $\Delta \mathrm{R}$ values. Australian Archaeology 63:57-60.

van der Kaars S, De Deckker P. 2002. A Late Quaternary pollen record from deep-sea core Fr10/95, GC17 offshore Cape Range Peninsula, northwestern Western Australia. Review of Palaeobotany and Palynology 120(1-2):17-39.

Waite A, Thompson P, Pesant S, Feng M, Beckley L, Domingues C, Gaughan D, Hanson C, Holl C, Koslow T. 2007. The Leeuwin Current and its eddies: an introductory overview. Deep Sea Research II 54(8-10): 789-96. 
Woo M, Pattiaratchi C, Schroeder W. 2006. Summer surface circulation along the Gascoyne continental shelf, Western Australia. Continental Shelf Research 26(1): 132-52.

Wyrwoll K, Greenstein B, Kendrick G, Chen G. 2009. The paleoceanography of the Leeuwin Current: implications for a future world. Journal of the Royal Society of Western Australia 92:37-51.

Yu K, Hua Q, Zhao J-X, Hodge E, Fink D, Barbetti M.
2010. Holocene marine ${ }^{14} \mathrm{C}$ reservoir age variability: evidence from ${ }^{230} \mathrm{Th}$-dated corals from South China Sea. Paleoceanography 25: PA3205, doi:10.1029/ 2009PA001831.

Zhu ZR, Wyrwoll KH, Collins LB, Chen JH, Wasserburg GJ, Eisenhauer A. 1993. High-precision U-series dating of Last Interglacial events by mass spectrometry: Houtman Abrolhos Islands, western Australia. Earth and Planetary Science Letters 118(1-4):281-93. 